\title{
Plural policing in england and wales: thoughts and discussion
}

\begin{abstract}
Plural policing can be described as a new way of looking at policing which may now have moved away from a police-centric view of the world, ${ }^{1}$ and includes a new way of viewing the social system that surrounds policing itself. In particular this involves the growth of the non -public sector policing provision of policing activities. When discussing exactly what is meant by policing, there has been a focus on discussing the topic purely from the view of the uniform services provided by the public police organisation. However, there is a need to move away from the idea that 'policing' is associated purely with the work of the uniformed public police alone. This is an important point that needs to be reinforced, but to understand the current and ongoing trend for plural policing we need to situate the present state (and future) of police activity. This article discusses the concept of plural policing and also considers examples from different countries in order to appreciate such important facets as police accountability and legitimacy within the democratic policing model.
\end{abstract}

Volume 6 Issue 5 - 2018

\author{
Colin Rogers \\ Professor of Policing and Law enforcement, Charles Sturt \\ University, Australia
}

\begin{abstract}
Correspondence: Colin Rogers, Professor of Policing and Law enforcement, Charles Sturt University, Australia,
\end{abstract}

Email corogiers@csu.edu.au

Received: August 13, 2018 | Published: November 19, 2018

\section{Policing in England and Wales- a brief context}

The current structure of 43 police forces in England and Wales reflects in part the historical fear of a national police force. The historical context of this concern can be found in the period before the introduction of the Metropolitan Police Act 1829, with the popular fear that a national police could easily become puppets of the government which could lead to anarchy and direct political control. People pointed to examples of the misuse of the police in European countries, particularly Revolutionary France to support this argument; hence the fragmentation of British police forces, with the accent on so-called 'local accountability'. However, as Jones ${ }^{2}$ points out, the general trend in recent times has been one of greater centralised control of local policing, with the Home Office exerting more influence and the establishment of national policing bodies such as the Serious Organised Crime Agency (now the National Crime Agency). Other national bodies include her Majesty's Inspectorate of Constabulary, the Audit Commission, and the Police Standards Unit amongst others who have been important actors in the national governance of policing in England and Wales. ${ }^{3}$ Whilst this may have been true of previous Labour governments the change in government from 2010 seems to have invoked a looser central control with the introduction of Police and Crime Commissioners, (PCCs) elected in November 2012 under the auspices of the Police and Social Responsibility Act ${ }^{4}$ and the end of ring fenced funding for community policing. The introduction of PCCs, with the revived funding arrangements for that post meaning PCCs can decide how to spend their budgets, introduces the possibility for further pluralisation of policing services.

Until recently, governments in the UK have sought to expand police numbers until by 2010 the number of police officers in England and Wales stood at 141,000. However, since that time large expenditure cuts have meant that currently, 20 per cent of funding for police has been removed. In the present climate of austerity measures, this economic reduction is likely to continue. In 2014, HMIC (2014) projected that there would be 16,300 fewer police officers in England and Wales in the near future. The latest information provided by the Home Office suggests a total of 122,404 police officers, a reduction in numbers of nearly 20,000 since 2010. However, of this number only 103, 837 officers were employed in frontline policing roles. ${ }^{5}$ Even through times when police numbers were being increased there is evidence to suggest that pluralisation of policing was being undertaken, albeit within the police organisation itself. The most obvious example was the introduction of Police Community Support Officers. Established by section 38 of the Police Reform Act 2002, these 'civilian' or unsworn officers are directed and controlled by the Chief Constable. They undergo much less rigorous training and have fewer legal powers than sworn officers. Because they are cheaper to employ than regular officers they are sometimes viewed as being the police's answer to competing with other (non-police) providers for local markets for patrol. ${ }^{4}$ Even before the introduction of PCSOs however, the widening of police provision was contained within the Crime and Disorder Act $1998,{ }^{6}$ which saw the formalisation of partnership working, and the introduction many other agencies, such as Local authorities, education and health provision, being involved in crime reduction work. In an interesting approach, Zedner ${ }^{7}$ suggests that the recent developments in policing are typical of an era that pre-dates the police themselves. She examines the historical aspect of crime control, and comes to the conclusion that the apparent monopoly of policing by the public police can be seen as an historical blip in the longer term pattern of multiple police providers and markets in security. The extent and import of changes in contemporary crime control are therefore hotly contested. By setting these changes in historical perspective, Zedner challenges claims that we are entering a new era in policing. Notwithstanding the changes in police numbers in England and wales, and the change in political philosophy, the problem remains of just what we mean by the concept of plural policing?

\section{Plural policing defined}

As Ian Loader ${ }^{8}$ points out, we have seen a shift from 'police' to 'policing' and this has resulted in the recent modification of the work of the state, both as a sole provider and as a broader, more diverse network of power. Loader suggests four distinct categories of policing, namely;

i. Private forms of policing have been secured through government;

ii. Transnational forms of policing are above government;

iii. The market in policing and security is beyond government;

iv. Policing activities engaged in by citizens themselves are consider below government. 
This suggests a world of plural, networked policing. Consequently, issues attached to an older, single-style delivery of policing, such as legitimacy, effectiveness, equity, and human rights now present themselves with regard to plural policing. Prenzler ${ }^{9}$ writing about the situation in Australia concurs, pointing to the fact that the time of governments being viewed as the natural monopoly of many basic services, including health, education and policing, may be at an end. Historically the role of the state as the sole provider of services, particularly policing, is not a consistent one. Johnston ${ }^{10}$ illustrates the fact that the field of private security history shows that private and other forms of non-police security have tended to dominate community business and individual forms of protection, in the face of a common situation of absent or inadequate state provision.

For Crawford et al., ${ }^{11}$ the term 'plural policing' is utilised for the following reasons:

i. It recognises the plurality of policing powers and personnel and acknowledges the existence of a mixed economy.

ii. It breaks free from the unhelpful dichotomy between 'public' and 'private' police, recognising that sometimes public police serve private and parochial interests and police private spaces or privately-owned spaces that have become public in character.

iii. It does not prioritise the role of any particular provider.

Wakefield ${ }^{12}$ believes that plural policing is the expanding role of non-police service providers in policing, and the variety of different public, private and voluntary bodies now engaged in the activity. Plural policing therefore refers to the patchwork of policing provision and authorisation which involves a mix of the police, municipal auxiliaries, commercial security and the activities of the citizens. This replaces the idea of the police being the sole proprietors of, or having a monopoly over, public security provision. The term 'pluralisation' itself appears to emanate from the early work of Stenning ${ }^{13,14}$ where they observed a change in the way formal social control was taking place, particularly in the increasing use of private security and an increase in different agencies delivering policing activities. Bayley and Shearing ${ }^{15}$ have argued that in modern democratic countries a watershed has been reached in terms of crime control and law enforcement, and that in the future people will view this time as one when an old system of policing ended and another took over. It appears that to some extent pluralised policing has already gained a substantial foothold in policing in the UK through recent innovations such as neighbourhood policing teams. It is of course tempting to assume that plural policing is limited to the UK only. However, this is far from the truth and a study of the introduction of plural policing in other European countries is a fruitful one when comparing it to a UK perspective. Even allowing for the different social and political make up of these countries, lessons may be learned from their experiences

\section{Plural policing- the European experience}

Terpstra, Spreeuwers et al., ${ }^{16,17}$ provide some useful information when considering the plural policing idea in other countries. They quite rightly point out that other agencies, both public and private, are now undertaking tasks that until quite recently were considered to be the tasks of the police alone, such as patrolling public spaces and the enforcement of social order. There now exist all kinds of non-police guards, patrollers, wardens and officers working in the public space under the gaze of the public. Consequently it is useful to appreciate and understand how the pluralisation of policing in other countries is being undertaken, as it may be of relevance to our own context. Of course, policing does not occur in a vacuum and whilst the UK has been subject to the application of neo-liberalism, this may not be the case for some other countries. Similar developments may have drastically different meanings in other social and cultural contexts, but may provide opportunities for learning and experience.

\section{Austria}

Austria has an entrenched legalistic culture with a strong political consensus that only the state should be responsible for policing and security matters. Consequently, its plural policing facilities are on a modest scale, with some local provision of two types of 'non-police' policing emerging since 2007. Between 15 to 20 municipal authorities created local organisations responsible for surveillance and some enforcement for minor infractions in public spaces. The reason for this development lies in the fact that over the past two decades the police have become focused upon national issues and fighting crime, with a detriment to local community-style policing. Municipalities and cities have tried to counter this movement by establishing local organisations, with some contracting private security guards to work in public spaces in order to provide a visible uniform presence. However, there is a problem with this approach in that they have no special powers, and whilst there appears to be an increase in their use, no special legislation is in place for their regulation. Consequently the presence of armed security guards on the street in Austria is not unusual, and the regulation of some 'non-police' policing appears to be fairly poor.

\section{Belgium}

Belgium has introduced different forms of policing since the 1990s in response to dissatisfaction with poor management of petty crime and social disorder. Therefore the government introduced job creation schemes for surveillance guards and community guards working in public areas. Further, legislation was introduced to give municipal authorities more power to manage petty crime etc. since around 2007. Consequently, 'community guard reporters' are enforcement officers entitled to report certain offences committed by people so that they may be fined or enter community service. However, the implementation of this approach appears to be fragmented across the country. That said, the public police are legally obliged to cooperate with the guards but not supervise them, which is the responsibility of the municipal authorities. Private security in Belgium plays only a limited role in the public space, with the current consensus that surveillance (patrol) and enforcement in public spaces should only be performed by state institutions. Consequently, the debate regarding the use of private security for public policing has not really occurred in Belgium to date.

\section{The netherlands}

The Netherlands appears to have a longer history of pluralised policing than most countries in Europe. The City Guards, or Stadswachten, were introduced mainly in city centres around 1989 with the task of patrolling public spaces, based not only upon security for the public but as part of a job creation scheme for the long-term unemployed..$^{18}$ However, from the mid-2000s these guards became employed by new and larger municipal departments of city surveillance or local enforcement. Some local governments now appoint Special Investigative Officers (SIO) who patrol public spaces and who also have limited powers to deal with low-level social disorder. It would appear that around 14 per cent of municipal governments in the Netherlands also contract for special occasions employees of private security firms as wardens or SIOs for working in public areas. The main reason apparently is the flexibility it allows the municipalities, who can contract and pay for individuals when there is a clear need for their services. In the Netherlands the police have formal responsibility 
for the daily or operational coordination of these wardens. However, it is the municipal authorities who are responsible for policy, budgets etc. which causes some problems in the implementation of the wardens schemes. Problems including poor exchange of information and poor direction in terms of leadership from the police organisation can occur, leading to difficult relationships between the police and the municipal authorities. Private security guards are often used as wardens in semi-public places such as business parks, malls and at large scale events, ${ }^{18}$ whilst a small number work in the public area, contracted by private agencies. Examples of this can be found in areas where the residents earn high incomes and can afford to pay for private patrolling. Consequently, in the Netherlands, there is a complex yet fragmented public and private provision of surveillance and enforcement officers working in public places. In general, the rise of the pluralised approach can be found in the fact that the public police had been gradually withdrawing since the 1990s, both from rural areas and from basic street patrolling duties, with less attention being paid to high visibility police work.

\section{Germany}

The Federal political system in Germany lends itself to a strong tradition of local self-government, and this impact upon the powers and responsibilities of the police. The police have responsibility for different aspects of law enforcement whilst local authorities have their own responsibilities for public safety and public order. ${ }^{19}$ Consequently the evolution of plural policing has not been as prevalent as in other countries such as the UK, even if the concept of neo-liberalism can be seen elsewhere in the political system. During the early 1990s, there appeared a reduction in the sense of community safety and wellbeing. This, coupled with economic problems and altered perceptions of crime and risks, led to some reforms and new interpretations of police duties. In addition, according to Freve $^{20}{ }^{20}$ the rise of the security market, which included such as home security etc. led to an increase in this type of provision which in turn pushed forward the idea of plural policing. In the main, municipal authorities deal with such as issues as public order and safety, with specialised departments that employ occasionally-uniformed staff who are involved in surveillance patrols and some enforcement. However they are not allowed to use coercive force. These city warden-type staff members can call the police if the situation demands it. With regards to police interaction with private security companies, this has tended to revolve around the traditional private security fields of patrols within private premises, building security etc. However, there appears to be a growing trend of visibility of uniformed security personnel in semi-public and public spaces. Despite recent changes in some areas of policing public space, Germany still primarily conforms to what Loader ${ }^{8}$ refers to as 'policing by government'. The police are a relatively well-regarded organisation in Germany and there have been some reservations regarding private security firms which do not have such public support. The consequence is that Germany still favours a lower grade of privatisation in the field of safety and security in terms of pluralised policing functions.

\section{Lessons learned}

Having considered a brief examination of different European countries' experiences of pluralised policing, most of these countries appears to have seen an increasing importance in the use of non-police providers of policing to a greater or lesser extent. The reasons for this seem to point to the police's failure to meet the expectation that they will be present in public spaces through surveillance patrols. This may be because of similar social and economic circumstances in each country; the rise in the night-time economy, raised expectations of security, and the rise of national and international threats to name a few examples. What may appear to have occurred is a shortage of resources to focus on so-called 'petty crime' and low-level disorder, which in turn has had a negative impact upon community feelings of safety and security. Consequently, the regular or public police have focused upon 'core tasks or functions' such as 'fighting crime' and dealing with the ever-increasing complexity and globalisation of the crime picture. The main negative impact of this has been seen and felt at the local level, where it is believed it impacts upon peoples' trust and support for the police (Innes 2014). As a result local solutions to this problem appear to be the main drivers for newer kinds of uniformed 'police', such as city guards, wardens or private security guards, who operate alongside the regular or public police. These roles are mainly controlled and supported by municipal authorities and, whilst they operate alongside regular police, are not managed or dominated by them. As Terpstra ${ }^{16}$ points out, what we see in continental European countries is an increasing importance of local authorities being responsible for local safety policies.

Despite what appears to be some resonance within the introduction of pluralised policing in these countries, there are of course some differences in the way non-police personnel operate. For example, some countries have a strict legal agreement regarding the way in which each group operates, with some close relationships between police and non-police personnel. On the other hand there can be some distance between police and security guards who carry out enforcement duties in public. Countries also differ in terms of the extent to which the private police carry out their function. Belgium currently has no private guards who have patrol and enforcement tasks in public, because the general consensus is that these tasks should remain in public hands. However, in the Netherlands local authorities can contract private security guards that may have some formal legal powers, whilst private security officers can be contracted by residents to provide security patrols.

\section{Problems of accountability}

An apparently contentious area when discussing any form of pluralised form of policing is that of accountability. Police provision is no longer monopolised by the public police; that is, the police entrusted by government with a monopoly on the use of statesanctioned force. ${ }^{19}$ Policing is now widely offered by institutions other than the state, most importantly by private companies on a commercial basis and by communities on a volunteer basis. The great advantage of public policing in democratic countries is that it is accountable to every citizen through the mechanisms of representative government. This is not the case for commercial private policing organisations, which are accountable - ultimately - to their shareholders. Established scholars such as Bittner ${ }^{22,23}$ have all contributed to the notion that full democratic policing cannot survive without accountability. In support of these seminal writers, one of the most important documents regarding democratic accountable policing in Europe is the 2008 publication by the Organisation for Security and Cooperation Europe (OSCE, 2008). This publication reinforces the key principles of democratic policing, ${ }^{24}$ in particular police accountability and transparency. Here, democratic policing requires that the police be and consider themselves to be accountable to;
i. The citizens
ii. Their representatives
iii. The state and
iv. The law. 
Therefore public police activities ranging from behaviour and attitude, strategies for police operations, appointment procedures and even budget management must be open to scrutiny by a variety of supervisory institutions. Furthermore, if a central feature of democratic policing is the consent of the people, prerequisites for gaining public support should be 'providing transparency in police operations and (ensuring) mutual understanding with the public the police serve and protect' (OSCE 2008:13). The recent introduction of Police and Crime Commissioners in England and Wales ${ }^{25}$ is considered partly to be a bridge between communities and the police as a mechanism to strengthen police accountability to the public. ${ }^{26}$ Police accountability requires police officers and the institutions to which they belong to explain, justify and answer for their conduct. Individual police officers are obliged to account internally to their supervisors and to an internal investigation unit, and in democracies, to external independent accountability institutions such as the Independent Police Complaints Commission in the UK. At a political level, police agencies commonly answer to a senior member of government such as a police minister. This political structure of accountability is influenced by the particular political system in the state. For example, a totalitarian state would regard the police as a 'tool' of the government. In democratic societies the police are required to;

i. Adhere to the law;

ii. Abide by due process when enforcing the law;

iii. Protect citizens' rights, both civil and political, within the power laid down by legislation.

Ultimately, despite the perceived laborious route involved in getting change introduced in the democratic political model, accountability to people does occur through their elected representation. What has been witnessed in many countries in the last decade or so has been a rise in external civilian regulatory bodies which have slowly become an acceptable feature of police accountability, for example the use of lay visitors in the UK. The role of external civilian regulatory bodies is to monitor, review and/or investigate alleged corruption and misconduct. Given that police accountability in the UK is, in the main, one the roles of local government, this type of approach would seem to fit adequately into any future accountability process. To be effective, the 'policing by consent' model requires the community to trust its police, and that trust is dependent upon police providers behaviour according to constitutional and legal processes established by the people through a freely-elected representative parliament. There is of course one perceived complication when discussing the idea of police accountability in England and Wales, and that is the idea of constabulary or operational independence. This idea highlights the difference between the government's right to formulate policing policy and state interference with operational policing decisions, including the exercise of policing powers. In other words, elected politicians can produce policy relating to what needs to be done by the police, but the way in which these policies are implemented is decided by the chief police officer for the particular police organisation...

Consequently 'operational independence' requires the police;

i. To have a high degree of professionalism and independence from political influences;

ii. To act in conformity with the law and established practice;

iii. To operate on the basis of public consent as evidenced by levels of public confidence;

iv. To take responsibility for their decisions and operations, accepting liability when required and to exhibit full transparency in decisions and openness to external scrutiny.
This is particularly important in terms of helping the police achieve full public confidence as this is the key to effective policing, where police functions can be carried out on the basis of legitimacy rather than force. As Jones ${ }^{2}$ rightly points out, the provision of pluralised policing, which includes both public and private bodies, introduces challenges for those responsible for ensuring policing is under the control and influence of the democratic policing model. He points to four main areas of concern, namely;

i. The range of providers of policing activities raises the question of identifying who they are and making sure their activities are visible and transparent.

ii. The complex provision of different agencies duplicating their efforts may impact upon the effectiveness of the approach.

iii. Specific sections or disadvantaged groups may be over or underpoliced if the plural policing approach is not delivered in an equal fashion.

iv. If the provision is fragmented it is more difficult for police services to be responsive to community needs and values.

Given the problems highlighted above, the challenge is of course to institute an accountability and governance strategy that deals with the full approach to pluralised policing. This strategy may be similar to the policing board index introduced in Northern Ireland as a result of the Patten Report. However, it may also include an enhanced role of the IPCC and the Policing Panel created in 2011. Concerns regarding accountability in a world of pluralised policing are real enough. There have been several instances where private security companies involved in public 'policing' activities appear to have been found wanting. For example, the reported actions of a private security firm, Close Protection UK, and the way in which they are alleged to have treated jubilee stewards, is an interesting case. Here it was reported that the security company had used unpaid jobseekers to steward the Queen's Diamond Jubilee celebrations in London, and that they were asked to sleep under London Bridge before the river pageant the following day. Whatever the truth of the situation surrounding this incident, it was the response from both the company and the government to complaints made that is of interest, particularly in the wider context of using private companies to provide policing activities. In response to the complaints, the company stated it had launched an investigation of its own whilst the government regarded the occurrence as a 'one-off' and an 'isolated incident' not worthy of note. Cleary this matter caused concern for all involved and other politicians were perturbed enough to raise the issue; indeed, it highlights wider concerns regarding public accountability when public policing activities are carried out by private companies. For the government, however, this incident appeared to be insignificant and it was reluctant to become involved. This attitude may not bode well for accountability in any future ${ }^{27}$ privatisation or pluralisation of policing activities, especially when individuals or private companies are called to account for their actions.

\section{Conclusion}

Defining plural policing can be problematic not least because of the different terminology in use to describe the concept. However, pluralised policing is not confined purely to England and Wales and has, to a greater or lesser extent, found its place in many countries. In other countries this approach is currently less popular, because profitmaking is seen as being incompatible with the ideals of impartial justice and universal service intrinsic to modern policing. There are challenges inherent in the use of plural policing approaches which may affect the very nature of the democratic policing model and these needs to be acknowledged and dealt with. Despite criticism of 
the future of pluralised policing, it would appear that private sector policing is likely to be an approach of increasing prominence in a mixed economy of policing provision, both as a low-cost frontline preventative presence and in specialist corporate operations. In addition, the notion of self-policing within communities and greater use perhaps of volunteers to assist in public provision of policing may all add to the possibly confused landscape of plural policing in the future in England and Wales.

\section{Acknowledgement}

None

\section{Conflict of interest}

The author declares that there is no conflict of interest.

\section{References}

1. Crawford A. Plural Policing. Newburn T, Neyroud P editors. Dictionary of Policing, Cullompton, Willan. 2008.

2. Jones T. The Accountability of Policing. T Newburn editor. The Handbook of Policing, Cullompton: Willan. 2008.

3. Jones T, Van Sluis A. National Standards, Local Delivery: Police Reform in England and Wales. German Policy Studies. 2009;5(2).

4. Home Office. The Police Reform and Social Responsibility Act, London. The Stationery Office. 2011.

5. Home Office. Police Workforce, England and Wales: 31 March 2018 2018.

6. Home Office. The Crime and Disorder act. London. The Stationery Office. 1998

7. Zedner L. Policing before and after the Police: The Historical Antecedents of Contemporary Crime Control. British Journal of Criminology. 2006;46(1):78-96.

8. Loader I. Plural Policing and Democratic Governance. Social and Legal Studies. 2000;9(323)

9. Prenzler T. Outsourcing of Policing Tasks: Scope and Prospects. Australian Security Industry. 2013

10. Johnston L. The Rebirth of Private Policing, London: Routledge. 1992;33(4):576-577.
11. Crawford A, Lister S, Blackburn S, et al. Plural Policing- The Mixed Economy of Visible Patrols in England and Wales. Bristol university press. 2005.

12. A Wakefield, J Fleming. The SAGE Dictionary of Policing. 2009.

13. Stenning PC, Shearing CD. Modern private security: its growth and implications. M Tonry, et al. editors. Crime and Justice: An Annual Review of research Vol 3. Chicago: University of Chicago Press. 1981.

14. Stenning PC, Shearing CD. Private security: implications for social control, Social Problems. 1983;30(5):498-505.

15. Bayley DH, Shearing CD. The Future of Policing. Law and Society Review. 1996;30(3):585-606.

16. Terpstra J, Stokkom Van B. Plural policing in Comparative PerspectiveFour Models of regulation. European Journal of Policing Studies. 2015;2(3):325-343.

17. Terpstra J, Stokkom Van B, Spreeuwers R. Who Patrols the Streets? 2013.

18. Hauber A, Hofstra B, Toornvliet L, et al. Some new forms of functional social control in the Netherlands and their effects. British Journal of Criminology. 1996;36(2):199-219.

19. Van Steden R, Sarre R. The Growth of Privatised Policing: Some Cross National Data and Comparison. International journal of Comparative and Applied Criminal Justice. 2007;31(1).

20. Frevel B. Pluralisation of Local Policing in Germany. Journal of Policing Studies. 2015;2(3):267-284.

21. Klockers C. Idea of Police. Sage. 1985.

22. Bittner E. The Functions of the Police in Modern Society. 1980.

23. Sklansky DA. Democracy and the Police, California, USA, Stanford University Press. 2008.

24. HMIC. State of Policing: The Annual Assessment of Policing in England and Wales 2017.

25. Rogers C, Gravelle J. UK Policing and Change: Reflections for Policing Worldwide, Review of European Studies. 2012;4(1): 42-51.

26. Ocse. Guidebook on Democratic Policing. 2007.

27. Blair I. 'Leading towards the Future', the Future of Policing Conference, LSE. 2003. 